Інноватика у вихованні. Випуск 12. 2020.

УДК 37(091)(477)

DOI: $\underline{10.35619 / \text { iiu.v1i12.321 }}$

\author{
Чижевський Борис \\ керівник секретаріату Комітету Верховної Ради \\ України з питань освіти, науки та інновацій, \\ кандидат педагогічних наук, \\ м. Київ, Україна \\ ORCID:0000-0002-7878-1180 \\ e-mail:chyzhevskyi@rada.gov.ua
}

\title{
ПЕДАГОГІЧНИЙ ПРОМЕТЕЙ!
}

Анотація. У статті узагальнено й схарактеризовано значення творчої спадщини видатного педагога, філософа, науковця, письменника, директора школи і талановитої Людини - Василя Олександровича Сухомлинського, який залишив для майбутніх поколінь дітей, їхніх батьків і вчителів незгасаючу науково-педагогічну i літературну спадщину. Для багатьох українських та зарубіжних вчителів він є своєрідним Прометеєм у педагогічному сузір'ї думок, порад і роздумів про дитину, про школу, їх яскраве майбутнє.

Твори В. О. Сухомлинського відомі сьогодні у виданнях різними мовами народів світу від болгарської до японської, від німецької до китайської, його педагогічна спадщина вивчається у в провідних університетах Європи, Азії, Канади, США і Австралії. Його унікальні наукові й філософсько-виховні твори друкуються в педагогічних журналах Польщі, Німеччини, Чехії, Словаччини, Румунії, Австрії, Іспанії, Фінляндії та інших країн. А його педагогічна спадщина як учителя i як директора школи знайшла численних послідовників серед педагогів шкіл різних країн. Лише в Китайській Народній Республіці більше 10 тисяч шкіл працюють за його методиками.

Педагогічна спадщина В. О. Сухомлинського - це 48 монографічних праць і брошур, два художні твори, понад 600 статей та близько 1500 оповідань і казок для дітей. Він вважав, що учителі несуть в народ світло знань, науки. На його глибоке переконання народ - живе, вічне джерело педагогічної мудрості, та якби у вчителів не було постійного духовного спілкування з людьми, вони не могли б успішно вчити і виховувати молоде покоління.

Основні ідеї, які розвинув Василь Олександрович у своїх працях: любов до дитини; розвиток творчих сил кожної окремої особистості, формування етикоестетичних цінностей, інтересів, потреб, які спрямовані виховання почуття прекрасного і гармонії; звернення до внутрішнього світу дитини, опора на іiі сили, внутрішні потенції; розвиток ідеї «радості пізнання», тобто емоційне сприйняття процесу навчання; демократизація структури управління навчальновиховним процесом у школі (психологічний і педагогічний семінари, школа для батьків тощо).

Ключові слова: Прометей, педагогічна спадщина В. О. Сухомлинського, Павлиська середня школа, концепція виховання, трудова школа.

Постановка проблеми. У кожного народу є особистості, які не підвладні часу. Такою непересічною особистістю для українського народу став Сухомлинський Василь Олександрович - видатний педагог, письменник, 
науковець, філософ, директор Павлиської середньої школи. Непохитна постать за викликами часу, просвітитель за покликом душі і серця, учитель за велінням долі, науковець за суттю своїх діянь, він оживив у науковому, освітньому і суспільному середовищі вічними ідеями торжества добра і гуманізму. Його мудрістю та мріями живилася українська педагогічна наука і практика в 50-70-х роках XX століття; досвід та напрацювання актуальні для сьогодення; праці, думки, роздуми та ідеї спрямовані в майбутнє, а критерії добра, гуманізму, людяності, премудрості, пізнання, навчання, знання, переконання - вічні.

Аналіз останніх досліджень 3 проблеми. Для багатьох українських та зарубіжних освітян В. О. Сухомлинський є своєрідним Прометеєм у педагогіці. Тому цілком сучасними є роздуми, рекомендації, поради, викладені у працях В. О. Сухомлинського - вдумливого філософа, науковця, учителя, письменника, учасника Другої світової війни, про що йдеться в наукових розвідках Н. Калініченко (2003), М. Мухіна (1983), О. Сухомлинської (2003), Г. Перебийніса (2003) та ін.

Мета статті: на основі аналізу історико-педагогічних досліджень та публікацій розкрити й схарактеризувати постать В. О. Сухомлинського як фундатора передової педагогічної думки і освітньо-виховної практики, що залишається актуальною сьогодні і буде такою у майбутньому.

Виклад основного матеріалу дослідження. Василь Сухомлинський - це Учитель із самобутнім оригінальним обличчям, 3 власним творчим почерком всесвітнього масштабу. Його праці, думки, міркування, роздуми, ідеї і сьогодні $є$ вкрай актуальні, необхідні та неоцінимі. Він органічно поєднав у своїй діяльності теорію 3 практикою, був неординарною, високоосвіченою особистістю, новатором своєї епохи, а його твори увійшли в скарбницю світової науково-педагогічної думки.

Як директор школи та учитель він був яскравою особистістю, його уроки були відкриті для відвідування представниками педагогічної громадськості держави, колег, батьків. Він ділився своїми творчими знахідками, планами, здобутками, радився 3 колегами та всебічно підтримував i пропагував педагогічних працівників Павлиської школи. Він сам постійно вчився і своїм прикладом спонукав учителів до системного навчання та самоосвіти (Сухомлинська, 2013).

Педагогічна спадщина В. О. Сухомлинського налічує 48 монографічних праць і брошур, два художні твори, понад 600 статей та близько 1500 оповідань i казок для дітей. Він був членом-кореспондентом Академії педагогічних наук РРФСР, членом-кореспондентом Академії педагогічних наук СРСР, Заслуженим вчителем УРСР. У 1968 році йому було присвоєно звання Героя Соціалістичної Праці. Його праці виходили і виходять масовими тиражами в багатьох країнах світу (Канада, Китай, Німеччина, Росія, США, Японія). Він став визнаним класиком педагогіки XX ст. Різноплановим і багатоаспектним є творчий доробок В. О. Сухомлинського. Його твори видані 53 мовами світу загальним тиражем майже 15 млн. примірників. Книгу «Серце віддаю дітям» перекладено 30 мовами світу, що витримала 54 видання.

Варто зауважити, що, наприклад, книги «Вічна тополя» (Казки, Оповідання, Етюди) - Нова Шкільна Бібліотека та «Я розповім вам казку» (Філософія для дітей) В. О. Сухомлинського надруковані у 2003 та у 2016 роках тиражами відповідно 5000 і 3000 примірників. А вибрані твори у п'яти томах 
В. О. Сухомлинського були видані в 1976 році загальним тиражем 90000 примірників.

Важливим джерелом творчості В. О. Сухомлинського слугувала класична педагогічна спадщина. Він широко використовував ті передові філософські, педагогічні ідеї минулого, які не втратили свого значення у наш час. Великий педагог підкреслював, що без знання досягнутого упродовж багатьох століть, без осмислення i використання теоретичної спадщини неможлива висока культура педагогічної праці сьогодні. Тому він часто звертався до творчості Я.А. Коменського, Ж.-Ж. Руссо, Й.-Ф. Песталоцці, Ф.-А. Дістервега, Г. Сковороди, К. Ушинського, М. Пирогова, Л. Толстого, Т. Шевченка, I. Франка, Лесі Українки, до творів Юліуса Фучика, Януша Корчака i, звичайно, до праць своїх сучасників-теоретиків педагогіки, дидактики та виховання, психологів, фізіологів, а також до творів класичної художньої літератури. У монографії «Павлиська середня школа» він писав: «Ідеї великих педагогів - Коменського, Песталоцці, Руссо, Ушинського, Дістервега, які спрямовували школу, вчителя, учня на пізнання навколишнього світу, вчили досліджувати та пояснювати те, що людина бачить, - переломлюється у нашій роботі стосовно до наших завдань виховання» (Сухомлинський, 1976).

Актуалізація В. О. Сухомлинським відомих з минулого педагогічних законів та істин означала піднесення їх на якісно новий рівень, вищий ступінь, підпорядкування їх завданням післявоєнної школи, цілям виховання громадянина. Осягаючи й переосмислюючи старе, педагог боровся за утвердження й розвиток нового.

Невичерпно багатим джерелом творчості В. О. Сухомлинського була народна педагогічна мудрість, найкращі виховні традиції українського народу. Він вважав, що учителі несуть в народ світло знань і науки. На його глибоке переконання, народ - це живе, вічне джерело педагогічної мудрості та якби у вчителів не було постійного духовного спілкування $з$ людьми, вони не могли б успішно вчити i виховувати молоде покоління. Прогресивна етнопедагогіка українського та інших народів безперестанно надихала думку i працю В. О. Сухомлинського, орієнтувала його на реалізацію ідей виховання в дітей та молоді безмежної любові до Вітчизни, глибокої любові до матері, батька, рідних, поваги до старших, сердечної чуйності та пошани до людей праці, дієвої готовності прийти їм на допомогу в біді, виховання старанності в роботі, трудової майстерності і кмітливості, дбайливого ставлення до природи, рідної землі, іiі багатств, виявлення патріотичних почуттів у щоденній діяльності і поведінці. Високо цінував В. О. Сухомлинський у народній педагогіці традиції мудрої любові батьків до дітей, гуманного, поєднаного 3 розумною вимогливістю, підходу до них, використання в навчанні і вихованні скарбів рідного слова, підпорядкування знань реальним потребам непростого життя, поступового загартування дитячого організму i, взагалі, дотримання прийнятих у народі та історично перевірених, природовідповідних способів виховання.

Багато про науково-педагогічний цех науковця, педагога, директора може розповісти його робочий кабінет, особиста бібліотека в Павлиській середній школі. Вони унікальні в своєму роді і наповнені як сучасною літературою, так і рідкісними науковими, енциклопедичними, філософськими, класичними, педагогічними, юридичними, нормативно-правовими, історичними та науковопопулярними виданнями i, фактично, являють собою власну майстерню, творчу лабораторію славетного педагога, що розпочинав свою роботу о п'ятій годині 
ранку та завершував іiі пізньої ночі. Ним сповідувався культ книги. Власна бібліотека В. О. Сухомлинського залишається неповторною науковоінформаційною, культурно-освітньою, історичною спадщиною Українського народу (Сухомлинська, 2013).

Його яскравими сучасниками, соратниками, товаришами, доброзичливими порадниками, послідовниками є: Ткаченко І. Г. - учитель фізики, директор середньої школи в с. Богданівка Знаменського району Кіровоградської області, Герой Соціалістичної Праці; Березняк С. С. - начальник головного управління шкіл Міністерства народної освіти УРСР (1954-1984), член Ради Миру України, Герой України (легендарний «майор Вихор»); Ярмаченко М. Д. - директор Науково-дослідного інституту педагогіки (з 1973 р), член-кореспондент (1974), дійсний член (1982) Академії педагогічних наук СРСР, академік, засновник Академії педагогічних наук України, президент (1992-1997) Академії педагогічних наук України; Савченко О.Я. - український педагог, віцепрезидент Національної академії педагогічних наук України, головний науковий співробітник відділу початкової освіти Інституту педагогіки НАПН України, академік, засновник Національної академії педагогічних наук України, заступник Міністра освіти України, доктор педагогічних наук, професор, Заслужений працівник освіти України, почесний професор багатьох вищих закладів освіти України, фахівець в галузі загальної педагогіки і дидактики початкової школи; Захаренко О. А. - учитель фізики і математики, директор Сахнівської середньої школи Корсунь-Шевченківського району, членкореспондент Академії педагогічних наук СРСР (1989), дійсний член Академії педагогічних наук України (1992). Цей перелік на практиці значно ширший (Антология педагогической мысли Украинской ССР, 1988; Березняк, 2008; Калініченко та Перебийніс, 2003).

Своїм життєвим подвигом В. О. Сухомлинський дав поштовх появи нового покоління педагогів-новаторів, як-то: Ш. Амонашвілі, І. Зязюна. С. Лисенкової, I. Волкова, В. Шаталова, М. Гузика, Є. Ільїна, Т. Гончарова, О. Рєзніка, М. Палтишева, I. Іванова, Е. Сазонова, А. Дубровського та інших. Вони розвивали в дітях прекрасний людський талант - захопленість своєю справою, навчати творити оточуюче життя за законами добра і краси, возвеличувати i облагороджувати почуття. Досвід педагогів-новаторів - технологічний, тобто педагогічні ідеї, суспільно вагомі і значимі для всіх, отримують втілення в конкретних прийомах, формах, методах, якими можна оволодіти (Історія української школи і педагогіки, 2003; Нариси з історії розвитку новаторських навчально-виховних закладів в Україні (XX століття), 2010).

Нове покоління українських педагогів - переможців міжнародних освітянських конкурсів, змагань, олімпіад констатували, що вони відточували свою педагогічну майстерність на основі науково-практичної спадщини українського народу, у тому числі В. О. Сухомлинського. Основними критеріями їхнього успіху є новизна ідей, форм, методів роботи конкретного учителя, педагогічного колективу, України; ефективність досвіду (підтвердження позитивними результатами впродовж багатьох років); можливість творчого застосування цього досвіду іншими учителями i колективами, природньо в залежності від їхніх індивідуальних, особистісних якостей, від умов, в яких проходить освітній процес.

Тому не випадково книги В. О. Сухомлинського присвячені, головним чином, конкретним проблемам духовно-морального, розумового, патріотичного, 
естетичного та фізичного виховання і навчання дітей та молоді, педагогізації батьків, методиці викладання мови і літератури в середній школі, особливостям та закономірностям становлення керівника школи, зростанню творчості вчителя тощо. Пропагуючи засадниче значення колективізму в учнів, В. О. Сухомлинський рішуче відкидав принцип виховання індивідуума через колектив як засаду, яка може завдати духовної травми вихованцеві. Віддаючи належне трудовому вихованню в школі, він виступав проти ранньої спеціалізації (3 15 років життя), передбаченої Законом «Про зміцнення зв’язку школи 3 життям».

Найважливішими працями В. О. Сухомлинського $є$ такі: «Воспитание коллективизма у школьников» (1956); «Трудовое воспитание в сельской школе» (1957); «Педагогический коллектив средней школы» (1958); «Виховання в учнів любові і готовності до праці» (1959); «Верьте в человека» (1960); «Як ми виховали мужнє покоління» (1960); «Виховання моральних стимулів до праці у молодого покоління» (1961); «Духовный мир школьника» (1961); «Людина неповторна» (1962); «Праця і моральне виховання» (1962); «Дума о человеке» (1963); «Нравственный идеал молодого поколения» (1963); «Шлях до серця дитини» (1963); «Щоб у серці жила Батьківщина» (1965); «Моральні заповіді дитинства і юності» (1966); «Трудные судьбы» (1967); «Павлышская средняя школа» (1969); «Сердце отдаю детям» (1969); «Народження громадянина» (1970); «Методика виховання колективу» (1971); «Разговор с молодым директором школы» (1973), «Как воспитать настоящего человека» (1975); «Мудрая власть коллектива» (1975) та багато інших.

За результатами сотні зустрічей і бесід 3 молодими вчителями, які тільки починають працювати, аналізу тисячі листів від них, вийшла книжка «Сто порад учителеві». Наприклад, одна 3 порад Василя Олександровича стосується знання: «Знати - це значить уміти застосовувати знання. Про знання можна говорити лише тоді, коли вони стають чинником духовного життя, захоплюють думку, пробуджують інтерес. Активність, життєвість знань - це вирішальна умова того, щоб вони повсякчас розвивалися, поглиблювалися. Знання лише тоді й живуть, коли розвиваються й поглиблюються. Тільки за умови розвитку знань здійснюється закономірність: чим більшими знання володіє учень, тим легше йому вчитися» ( Сухомлинський, 1976, с. 452).

Навчаючи інших, Василь Сухомлинський постійно вчився сам, збагачував свої знання, був у стані постійного розвитку, подолання нових висот, вів за собою до нових висот. Його кандидатська дисертація на тему «Директор школи - керівник навчально-виховного процесу» та праці «Педагогический коллектив средней школы» (1958), «Система роботи директора школи» (1959), «Разговор с молодым директором школы» (1973) є актуальними як у наш час, так і в майбутньому.

Зокрема, грунтовно В. О. Сухомлинський досліджував проблеми теорії i методики виховання дітей у школі й родині, всебічного розвитку особистості учня, педагогічної майстерності, у цілісному вигляді сформував загальногуманістичні педагогічні ідеї довіри і поваги до дитячої особистості: погляд на навчальну діяльність як на насичений творчими відкриттями процес пізнання і самопізнання; обмеження сфери впливу колективу на особистість; виховання без покарань; підвищення ролі слова i особистості вчителя у виховному процесі. Ці ідеї часто викликали жорстку та неадекватну критику 3 боку офіційної педагогіки, проте В. О. Сухомлинський продовжував розвивати 
їx, приділяючи особливу увагу проблемам самоцінності кожної особистості, вільному розвитку дитини, включенню соціального середовища в сферу педагогічних впливів, природному вихованню. Він постійно звертався до етнопедагогіки, обстоював народні імперативи та цінності, вводив їх в усі ланки педагогічного процесу. Василь Олександрович своїм прикладом довів, що бути освітянином - це нелегка, часом подвижницька, але надзвичайно шляхетна праця, спрямована у майбутнє, - це мистецтво, обране за покликом серця.

Чимало педагогічних закономірностей та принципів виявив і розтлумачив В. О. Сухомлинський. Він обгрунтував власну концепцію виховання як розвитку творчих сил особистості в умовах колективної співдружності на основі спільних етико-естетичних цінностей, інтересів та потреб. У своїх пошуках він йшов від школи навчання, спрямованої на розвиток інтелекту, до трудової школи як основи розвитку дітей та підготовки їх до життя, де основним засобом виховання стає педагогічно обгрунтована й методично спрямована праця.

Він постійно порушував i розв'язував проблеми формування у молоді національного й естетичного світогляду. Як про один із шляхів успішного розв'язання цієї проблеми писав, що в душі дітей мають увійти найкращі народні традиції, які повинні стати святим законом, бо не можна уявити народ без імені, без пам'яті, без історії. У дусі кращих українських культурноісторичних традицій видатний учитель-новатор констатував, що мудрість $\epsilon$ найважливішою прикметною рисою людини. Його праці рясніють висловами на зразок: «мудра людська любов», «мудрість жити», «гідність - це мудрість тримати себе в руках». Педагог цілеспрямовано формував у кожного вихованця вміння бути маленьким філософом, осмислювати світ через красу природи. Для нього формування естетичного почуття дитини та їі емоційної культури було основним завданням гуманістичного виховання. А сприйняття й осмислення прекрасного - основа естетичної культури, без якої почуття лишаються глухими до всього високого й благородного (Герої - освітяни і науковці України, 2012; Коцур, В. та Коцур, А., 1999).

Ідеї книги «Серце віддаю дітям» мають загальнолюдське визнання i підтверджені іншими роботами та щоденною копіткою працею великого вчителя. Він наголошував що найголовнішим у його житті була любов до дітей.

У квітні 1970 року В. О. Сухомлинський завершив роботу «Проблеми виховання всебічно розвинутої особистості» - доповідь для захисту докторської дисертації за сукупністю праць, яку, на жаль, не встиг захистити. Усі твори Василя Олександровича дають переконливе уявлення не тільки про різнобічність його педагогічних підходів, але й про цілісність усього його педагогічного мислення.

Праці В. О. Сухомлинського стосуються не тільки педагогіки навчання, це також особливий матеріал, який надзвичайно актуальний у наш час в аспекті гармонізації сімейного виховання учнів. Навіть побіжного погляду достатньо, аби зрозуміти основну дилему, яку вирішував учитель-патріот у родинах павлиських селян: або подолання анархії в сімейно-шкільному вихованні молоді, або поступовий розпад існуючих соціальних відносин, як мінімум - на рівні селища. Всебічний розвиток особистості можливий лише там, де $є$ два вихователі - школа і сім'я, що діють одностайно, поділяють одні й ті ж переконання, виходячи 3 тих самих засад i принципів. При цьому не допускається розходження ні в меті, ні в суті, ні в засобах виховання. 
Спільно з учителями Павлиської школи Василь Олександрович вибудував таку систему роботи 3 батьками, яка допомогла б їм оволодіти основами батьківської педагогіки та мистецтва виховання. Чи не вперше в Україні тут діяла не лише для дітей, а й для батьків школа, де для них проводилися лекції і бесіди 3 педагогами та психологами, спрямовані, зокрема, на практику виховання. Отже, В. О. Сухомлинський вважав, що дитячий егоїзм, жорстокість, хамство, невдячність, байдужість, лицемірство породжуються вадами сімейного виховання. На його думку, піклування про успіхи в навчанні учнів мають починатися з піклування про те, що їсть і як спить дитина, яке її самопочуття, як вона грається, скільки годин протягом дня буває на свіжому повітрі, яку книжку читає і яку казку слухає, що малює і як висловлює в малюнку свої думки й почуття, які емоції пробуджує в іії душі музика природи, яка улюблена казка $є$ у дитини, наскільки чутливо сприймає вона радощі й негаразди людей, що вона створила для інших і які почуття пережила у зв'язку з цим.

Видатний педагог переконував, що перед кожною дитиною, навіть найважчою, вчитель повинен відкрити ті сфери, де вона зможе досягти своєї вершини, сформувати свою людську гідність, свою душу. Тому й створив «Азбуку моралі», яка вчила осягати суть добра i зла, честі й безчестя. Така азбука стала засобом реалізації емоційної необхідності відкривати здатність відчувати стан інших, вміння ставити себе на місце іншої людини. Одним із проявів цього є ідея особистісного підходу до роботи 3 дітьми, який грунтується на повазі, дбайливому ставленні до маленької людини як до найвищої цінності, iii права на свободу і гідність як неповторної індивідуальності. Ця позиція В. О. Сухомлинського є взірцем педагогічної мудрості, у якій втілено досвід учителя, за чиїми плечами важкі роки творчої праці. Вона призначена не просто для осмислення філософських роздумів видатного педагога, а й має велике значення для практики сьогодення 3 огляду на складність завдань, що стоять перед сучасною школою.

Не менш актуальною є позиція великого педагога у тому, що у школі вчать не тільки читати, писати, думати, пізнавати навколишній світ та багатства науки i мистецтва, а також у школі вчать жити, у школі вчаться жити. В. О. Сухомлинський вбачав у сучасній школі не лише освітню інституцію, а передусім - громадський центр і традиційний духовний осередок місцевої спільноти, який має сприяти розвиткові демократичної політичної культури, формуванню громадянської компетентності та відповідальності молодих людей.

Праці великого педагога-гуманіста є невичерпним джерелом ідей, мудрості, натхнення для сучасних педагогів. Екстраполюючи ідеї В. О. Сухомлинського на українське сьогодення, можна стверджувати, що головними завданнями нової школи і вчителя мають стати виховання людяності, формування свідомого громадянина, який виявляє готовність та бере безпосередню участь у житті своєї спільноти, об'єднання і держави (Сухомлинська, 2016).

Василь Олександрович Сухомлинський був і залишається педагогом і за суттю, i за духом. Розроблена українським вченим педагогічна система збагатила педагогічну науку новаторськими ідеями й положеннями, значно розширила теорію та освітню виховну практику i стала своєрідним революційним етапом у розвитку вітчизняної і світової педагогічної думки, що заслуговує сьогодні на нове осмислення і становлення у планетарному вимірі педагогічної науки. 
Дбаючи про щасливе прийдешне свого народу, В. О. Сухомлинський, як ніхто інший у вітчизняній педагогіці, мужньо ставив проблему формування у молоді національного і естетичного світобачення. Його гуманістичні ідеї - це ідеї становлення позитивного гармонійного майбутнього. Те, що він залишив нащадкам, підносить його як великого Духівника власного народу, як мислителя, який бачив крізь епоху. Праці та здобутки Василя Олександровича свідчать про широкий спектр його обдарувань, ясний розум, сильний характер, стійку волю, кмітливість, творчу винахідливість і глибоку прозірливість. Його педагогічні роздуми багато в чому випереджали час, формували той фундаментальний пласт, від якого беруть джерела педагогічні вчення й роздуми педагогів XXI століття, і сьогодні вони $є$ одним 3 інтелектуальних містків відповідності України принципам Європейського Союзу, а також Європейського Союзу - Україні. Його кредо «немає жодної педагогічної закономірності, немає жодної істини, яка була б абсолютно однаково застосована до всіх дітей» $\epsilon$ дороговказом для наукових та педагогічних працівників (Сухомлинська, 1976).

Актуальними і сучасними $є$ погляди В. О. Сухомлинського про те, що педагогіка - це не тільки наука, а й мистецтво, тобто висока майстерність i професіоналізм, які базуються на грунтовних теоретичних знаннях, на свідомому і вмілому використанні об'єктивних закономірностей та вимагають, водночас, і творчого виявлення індивідуальності вчителя, вихователя, його натхнення, ініціативи, винахідливості, вправності. На думку В. О. Сухомлинського, педагогіка включає в себе й елементи мистецтва в широкому значенні цього поняття, оскільки вона спрямовує освітньо-виховний процес, оперуючи не лише науковими категоріями (хоча це, звичайно, основне), а й художніми образами. Адже педагогіка подібно до мистецтва, зокрема мистецтва слова, служить справі формування найтоншої і найскладнішої сфери життя - внутрішнього світу людини, iї душі. Тож, невипадково багато творів В. О. Сухомлинського («Шлях до серця дитини», «Дума про людину», «Важкі долі», «Листи до сина» та інші) мають стиль художньої публіцистики, вони розраховані не тільки на раціональне, строго логічне осмислення ідей, а й на емоційно-естетичне їх сприйняття. Він розвивав ідеї А. С. Макаренка - «дух романтика». Тому він надавав романтичного забарвлення позакласній $\mathrm{i}$ позашкільній роботі з учнями, вихованню дітей на лоні природи («Школа під Голубим Небом»), оперував у своїй виховній практиці такими урочисторомантичними найменуваннями, як «Сад Матерів», «Сад Здоров'я», «Діброва Героїв», «Кімната Казки», «Кімната Слави», «Куточок Краси», «Острів Чудес», «Тополя Матері», «Яблуня Матері», (Батька, Бабусі, Дідуся, Брата, Сестри), «Свято Першого Хліба», «Свято Троянди», «Свято Книги» та ін.

Голос В. О. Сухомлинського і в наші дні звучить в Україні та світі, спонукає нас до прогресивних реформ в освіті, підвищення ії іміджу та забезпечення конкурентоздатності у світі. Вартий також наслідування основний принцип його життєтворчості, який полягає в тому, що Батьківщині, як рідній матері, боляче, коли ти не став справжньою людиною. Він радив жити і працювати так, щоб Батьківщина пишалася тобою.

Постановою Верховної Ради України було затверджено, розпорядженням Кабінету Міністрів врегульовано, а рішенням ЮНЕСКО підтримано відзначення у 2018 році 100-річчя від дня народження Василя Олександровича Сухомлинського. Український педагогічний корабель іде своїм вивіреним 
курсом! (Василь Олександрович Сухомлинський: до 100-річчя від дня народження: біобібліогр. покажч, 2018).

Вшановування спадщини видатного педагога мало на меті не просто засвідчити повагу до одного 3 найавторитетніших педагогів і гуманістів XX-го століття, а й наочно продемонструвати розуміння широким загалом значущості, життєдайності та актуальності його вчення для сучасної педагогічної науки, для виховання майбутніх поколінь. Не менш важливим $є$ завдання оцінити та практично застосовувати викладений у книгах i апробований на практиці підсумок копіткої дослідницької, щоденної праці, що становить зрілий і науково обгрунтований вклад у розробку провідних проблем дидактико-виховної роботи та переконливо розкриває активний характер сфери освіти, розроблюваної і застосовуваної відповідно до вимог духовних (натуральних), природних, педагогічних та юридичних законів.

Своїм прикладом В. О. Сухомлинський продемонстрував незламність духу, він не скорився, не піддався проявам зла, а був провідником добра, усього нового, красивого. Водночас застерігав, що необхідно із самого початку усвідомити сутність сучасного, передового, прогресивного, цивілізаційного взаємозв'язку власних досвіду та практики з тим, що заслуговує на запозичення, трансформацію і впровадження. Тому необхідно створити реальні умови для пізнання, осмислення, адаптації та використання досвіду інших країн, шкіл і вчителів. Праці видатного українського педагога-новатора не втратили своєї актуальності, їх необхідно постійно уважно перечитувати, адже вони вчать мислити, вдумливо підходити до виконання навчально-виховних завдань, враховуючи своєрідність i неповторність конкретних педагогічних явищ, процесів, зважаючи на особливості роботи, історію та позитивні традиції кожної школи (Актуальні проблеми сучасних історико-педагогічних досліджень шкільної освіти, 2014; Антологія текстів 3 реформування освіти в Україні: програми, концепції, проєкти (1991-2017): хрестоматія, 2019).

Висновки і перспективи подальших розвідок. За В. О. Сухомлинським необхідно звіряти нові освітянські починання, зміни та реформи в Україні тому, що його життєвим принципом є дарувати людям добро, тепло і світло серця, навчати законам пізнання та захищати дітей, учнів, слабких i нещасних, знедолених. Адже саме Василь Сухомлинський умів, як ніхто інший вкладати в дитячі серця думку і роздуми. Тому є своєрідним, поміркованим, об'єктивним та незалежним експертом усіх педагогічних інновацій, саме тим променем, який спрямовує нас до пошуку та утвердження істини. Тому грунтовне вивчення i творче використання його педагогічної спадщини - моральний і професійний обов’язок кожного керівника, науковця, педагога, українського політика, всіх, хто причетний до науково-освітньої сфери.

Перспективи подальших досліджень вбачаємо у вивченні педагогічної спадщини В. О. Сухомлинського як засновника створення освітньо-виховного середовища школи, залучення учнів до самостійної творчої праці, взаємодії сім’ї, громади і школи.

\section{СПИСОК ВИКОРИСТАНИХ ДЖЕРЕЛ}

Калініченко, Н. та Перебийніс, Г. (2003). Сучасники В. О. Сухомлинського. Кіровоград. 308 с.

В. А. Сухомлинський об умственном воспитании. (1983). Сост. и авт. вступ. ст. М.И. Мухин. К.: Радянська школа. 224 с. 
Сухомлинська, О. (2003). Історико-педагогічний прочес: нові підходи для загальних проблем. Київ: А.П.Н., 68 с.

Сухомлинська, О. (2013). Школа Сухомлинського у Павлиші - погляд крізь призму часу. Київ: Педагогічна думка. 124 с.

Сухомлинський, В. (2003). Вічна тополя. Казки. Оповідання. Етюди: Для молод. шк. віку. [Упоряд. О. Сухомлинської, заг. ред. передм. Д. Чередниченка]. Київ: Генеза. 272 с.

Сухомлинський, В. (2016). Я розповім вам казку ... Філософія для дітей. [Василь Сухомлинський / укладач Сухомлинська О. В.] Харків: ВД «ШКОЛА». $576 \mathrm{c}$.

Сухомлинський, В. (1976). Павлиська середня школа. Вибр. тв.: у 5 m. К.: Рад. шк. Т.4. с. 7-390

Антология педагогической мысли Украинской ССР. (1988). Сост. Н.П. Калениченко. М.: Педагогика, 640 с.

Березняк, С. (2008). Вибрані педагогічні праці. У 3-х томах. За ред. академіка АПН України М.Д. Ярмаченка. 2-ге вид., доповн. К.: НПУ імені М.П. Драгоманова.

Історія украӥнської иколи і педагогіки: Хрестоматія. (2003). Упоряд. О. О. Любар. К.: Т-во «Знання», КОО. 766 с.

Нариси з історії розвитку новаторських навчально-виховних закладів в Україні (ХX століття). (2010). За ред. О.В. Сухомлинської, В.С. Курила. Луганськ: Вид-во ДЗ «ЛНУ імені Тараса Шевченка». 444 с.

Сухомлинський, В. (1976). Сто порад учителеві. Вибр. тв.: у 5 m. Київ: Рад. шк. Т.2. С. 419-654.

Герої-освітяни і науковці Украӥни. (2012). Упоряд.: О.А. Сай та ін. 2-ге вид, перероб. К.: Генеза, 464 с.

Коцур, В. та Коцур, А. (1999). Історіографія історії Украӥни: курс лекиій. Чернівці: Золоті литаври. 520 с.

Сухомлинська, О. В. (2016). Мета стратегії розвитку загальної середньої освіти. Педагогіка і психологія. Вісн. НАПН України, 4, С. 11-13

Василь Олександрович Сухомлинський: до 100-річчя від дня народження: біобібліогр. покажч. (2018). НАПН України, ДНПБ України ім. В. О. Сухомлинського; упоряд. О. В. Сухомлинська, Л. Д. Березівська, Л. І. Страйгородська та ін. Вінниця: Твори. 395 с.

Актуальні проблеми сучасних історико-педагогічних досліджень икільної освіти. (2014). Всеукраїнська історико-педагогічної науково-практичної конференції. Київ: Інститут педагогіки НАПН України, 112 с.

Антологія текстів з реформування освіти в Україні: програми, концепції, проекти (1991-2017): хрестоматія. (2019). НАПН України, ДНПБ України ім. В. О. Сухомлинського; упоряд.: Сухомлинська О. В., Березівська Л. Д., Гавриленко Т. Л. та ін. Вінниця: ТОВ «ТВОРИ». 526 с.

\section{REFERENCES}

Kalinichenko, N. ta Perebyinis, H. (2003). Suchasnyky V. O. Sukhomlynskoho. [Contemporaries of V.O. Sukhomlynskyi]. Kirovohrad. 308 s. [in Ukrainian]

V. A. Sukhomlinskiy ob umstvennom vospitanii [V.A. Sukhomlinskiy on mental education]. (1983). Sost. y avt. vstup. st. M.Y. Mukhyn. K.: Radianska shkola. 224 s. [in Russian] 
Sukhomlynska, O. (2003). Istoryko-pedahohichnyi protses: novi pidkhody dlia zahalnykh problem. [Historical and pedagogical process: new approaches to general problems]. Kyiv: A.P.N., 68 s. [in Ukrainian]

Sukhomlynska, O. (2013). Shkola Sukhomlynskoho u Pavlyshi - pohliad kriz pryzmu chasu. [Sukhomlinsky's school in Pavlysha - a look through the prism of time]. Kyiv: Pedahohichna dumka. 124 s. [in Ukrainian]

Sukhomlynskyi, V. (2003). Vichna topolia. Kazky. Opovidannia. Etiudy: [Eternal poplar. Tales. Story. Studies] Dlia molod. shk. viku. Uporiad. O. Sukhomlynskoi, zah. red. peredm. D. Cherednychenka. Kyiv: Heneza. 272 s. [in Ukrainian]

Sukhomlynskyi, V. (2016). Ya rozpovim vam kazku ... Filosofiia dlia ditei. [I will tell you a fairy tale... Philosophy for children]. Vasyl Sukhomlynskyi, ukladach Sukhomlynska O. V. Kharkiv: VD «ShKOLA». 576 s. [in Ukrainian]

Sukhomlynskyi, V. (1976). Pavlyska serednia shkola. Vybr. tv.: u 5 t. [Pavlyska secondary school. Selected works.: in 5 vol. K.: Rad. shk. T.4. s. 7-390. [in Ukrainian]

Antologiya pedagogicheskoi mysly Ukrainskoi SSR. [Anthology of pedagogical thought of the Ukrainian SSR] (1988). Sost. N.P. Kalenichenko. M.: Pedagogika, 640 s. [in Russian]

Berezniak, Ye. (2008). Vybrani pedahohichni pratsi. U 3-kh tomakh.[Selected pedagogical works. In 3 volumes]. Za red. akademika APN Ukrainy M.D. Yarmachenka. 2-he vyd., dopovn. K.: NPU imeni M.P. Drahomanova. (in Ukrainian)

Istoriia ukrainskoi shkoly i pedahohiky: Khrestomatiia. [History of Ukrainian school and pedagogy: Reader]. (2003). Uporiad. O. O. Liubar. K.: T-vo «Znannia», KOO. 766 s. [in Ukrainian]

Narysy z istorii rozvytku novatorskykh navchalno-vykhovnykh zakladiv v Ukraini $(X X$ stolittia $)$. [Essays on the history of the development of innovative educational institutions in Ukraine (XX century)]. (2010). Za red. O.V. Sukhomlynskoi, V.S. Kuryla. Luhansk: Vyd-vo DZ "LNU imeni Tarasa Shevchenka". 444 s. [in Ukrainian]

Sukhomlynskyi, V. (1976). Sto porad uchytelevi. Vybr. tv.: u 5 t.[One hundred tips for teachers]. Kyiv: Rad. shk. T.2. S. 419-654. [in Ukrainian]

Heroi - osvitiany i naukovtsi Ukrainy. [The heroes - educators and scientists of Ukraine](2012). Uporiad.: O.A. Sai ta in. 2-he vyd, pererob. K.: Heneza, 464 s. [in Ukrainian]

Kotsur, V. ta Kotsur, A. (1999). Istoriohrafiia istorii Ukrainy: kurs lektsii. [Historiography of the history of Ukraine: a course of lectures]. Chernivtsi: Zoloti lytavry. 520 s. [in Ukrainian]

Sukhomlynska, O. V. (2016). Meta stratehii rozvytku zahalnoi serednoi osvity. [The purpose of the strategy for the development of general secondary education]. Pedahohika i psykholohiia. Visn. NAPN Ukrainy, 4, S. 11-13. [in Ukrainian]

Vasyl Oleksandrovych Sukhomlynskyi: do 100-richchia vid dnia narodzhennia: biobibliohr. pokazhch. [Vasyl Oleksandrovych Sukhomlynskyi: to the 100th anniversary of his birth: biobibliogr. index] (2018). NAPN Ukrainy, DNPB Ukrainy im. V.O. Sukhomlynskoho; uporiad. O.V. Sukhomlynska, L.D. Berezivska, L.I. Straihorodska ta in. Vinnytsia: Tvory. 395 s. [in Ukrainian]

Aktualni problemy suchasnykh istoryko-pedahohichnykh doslidzhen shkilnoi osvity. [Current problems of modern historical and pedagogical research of school education]. (2014). U : Vseukrainska istoryko-pedahohichnoi naukovo-praktychnoi konferentsii. Kyiv: Instytut pedahohiky NAPN Ukrainy, 112 s. [in Ukrainian]

Antolohiia tekstiv $z$ reformuvannia osvity $v$ Ukraini: prohramy, kontseptsii, proekty (1991-2017): khrestomatiia. [Anthology of texts on education reform in 
Ukraine: programs, concepts, projects (1991-2017): textbook]. (2019). NAPN Ukrainy, DNPB Ukrainy im. V.O. Sukhomlynskoho; uporiad.: Sukhomlynska O. V., Berezivska L. D., Havrylenko T. L. ta in. Vinnytsia: TOV «TVORY». 526 s. [in Ukrainian].

\title{
PEDAGOGICAL PROMETHEUS!
}

\author{
Borys Chyzhevskyi \\ Head of the Secretariat of the Verkhovna Rada \\ Committee of Ukraine on education, science and innovation, \\ Candidate of Pedagogical Sciences, \\ Kyiv, Ukraine \\ ORCID: 0000-0002-7878-1180 \\ e-mail: chyzhevskyi@rada.gov.ua
}

\begin{abstract}
The article deals with the significance of the creative heritage of the outstanding teacher, philosopher, scientist, writer, leader Vasyl Oleksandrovych Sukhomlynsky in the past, present and future. For many Ukrainian and foreign teachers, he is a kind of Prometheus in pedagogy, since the reflections, recommendations, advice set forth in V. O. Sukhomlynskyi's works are quite modern. As a school director and teacher, he was a bright personality, his lessons were open to attendance by representatives of the pedagogical community of the state, colleagues, and parents. He shared his creative discoveries, plans, achievements, consulted with colleagues and comprehensively supported and promoted the activities of teachers of Pavlyska school.

V. O. Sukhomlinskyi's pedagogical heritage includes 48 monographs and brochures, two works of art, more than 600 articles and about 1,500 stories and fairy tales for children. He believed that teachers bring to the people the light of knowledge and science. He was deeply convinced that the people are a living, eternal source of pedagogical wisdom, and if teachers did not have constant spiritual communication with people, they would not be able to successfully teach and educate the younger generation. V. O. Sukhomlynskyi substantiated his own concept of education as the development of creative forces of the individual in a collective community on the basis of common ethical and aesthetic values, interests and needs. In his search, he went from a school of instruction aimed at developing the intellect, to a labor school, as the basis for the development of children and preparing them for life, where the main means of education becomes pedagogically grounded and methodically directed work.
\end{abstract}

Equally relevant is the position of a great teacher that the school teaches not only to read, write, think, learn about the world and the riches of science and art, but also the school teaches to live, the school teaches to live.

Key words: Prometheus, pedagogical heritage of V. O. Sukhomlynskyi, Pavlyska school, concept of education, labor school.

Стаття надійшла до редакиї 07. 09. 2020 р. 